\title{
Toxic effects of the interaction of titanium dioxide nanoparticles with chemicals or physical factors
}

This article was published in the following Dove Press journal:

International Journal of Nanomedicine

17 July 2013

Number of times this article has been viewed

Kui Liu

Xialu Lin

Jinshun Zhao

Public Health Department of Medical School, Zhejiang Provincial Key Laboratory of Pathological and Physiological Technology, Ningbo

University, Ningbo, Zhejiang Province, People's Republic of China
Correspondence: Jinshun Zhao Public Health Department of Medical School, Zhejiang Provincial Key Laboratory of Pathological and Physiological Technology, Ningbo University, Ningbo 3I52II, Zhejiang Province, People's Republic of China Email zhaojinshun@nbu.edu.cn

\begin{abstract}
Due to their chemical stability and nonallergic, nonirritant, and ultraviolet protective properties, titanium dioxide $\left(\mathrm{TiO}_{2}\right)$ nanoparticles (NPs) have been widely used in industries such as electronics, optics, and material sciences, as well as architecture, medicine, and pharmacology. However, increasing concerns have been raised in regards to its ecotoxicity and toxicity on the aquatic environment as well as to humans. Although insights have been gained into the effects of $\mathrm{TiO}_{2} \mathrm{NPs}$ on susceptible biological systems, there is still much ground to be covered, particularly in respect of our knowledge of the effects of the interaction of $\mathrm{TiO}_{2} \mathrm{NPs}$ with other chemicals or physical factors. Studies suggest that interactions of $\mathrm{TiO}_{2} \mathrm{NPs}_{\mathrm{s}}$ with other chemicals or physical factors may result in an increase in toxicity or adverse effects. This review highlights recent progress in the study of the interactive effects of $\mathrm{TiO}_{2} \mathrm{NPs}_{\text {with }}$ other chemicals or physical factors.
\end{abstract}

Keywords: titanium dioxide, $\mathrm{TiO}_{2}$, nanoparticles, interaction, chemicals, physical factors

\section{Introduction}

Nanoparticles (NPs) are raw materials used in nanotechnology, with a size range of $1-100 \mathrm{~nm}$ in no less than one of their three dimensions. ${ }^{1-3}$ Titanium dioxide $\left(\mathrm{TiO}_{2}\right)$ NPs consists of three polymorphs, including anatase, rutile, and brookite. ${ }^{4} \mathrm{TiO}_{2} \mathrm{NPs}$ have been widely used in many products, such as toothpastes, sunscreens, cosmetics, food products, pharmaceuticals, and nanomedical reagents. ${ }^{5} \mathrm{TiO}_{2}$ particles have been considered as nontoxic mineral particles and traditionally used in the fields of cosmetics, food, and drugs. They were even used as "dust negative control" in many in vitro and in vivo toxicological investigations for many years. ${ }^{3,6}$ However, research evidence suggests that $\mathrm{TiO}_{2}$ NPs may possess higher toxicity potential than their bulk materials. ${ }^{5,7,8} \mathrm{Zhao}$ et $\mathrm{al}^{8}$ found that $\mathrm{TiO}_{2}$ NPs caused higher cytotoxicity than fine particles in cell culture. Due to their very small size, NPs can penetrate basic biological structures, which may, in turn, disrupt their normal function. ${ }^{3,9}$ Recent research evidence shows that $\mathrm{TiO}_{2}$ NPs may induce cellular toxicity effects in cardiac tissue. ${ }^{10}$ The toxicity effects of $\mathrm{TiO}_{2}$ particles were also observed in cells of the circulatory system. Li et $\mathrm{al}^{6}$

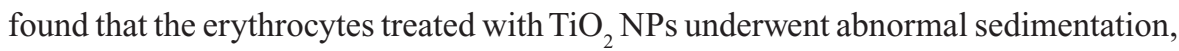
hemagglutination, and hemolysis, which were totally different from those treated with $\mathrm{TiO}_{2}$ fine particles. Lung tumors were also found in rats after lifetime exposure to high concentrations of $\mathrm{TiO}_{2}$ particles. ${ }^{11}$ Moreover, a recent study showed oxidative stress in mice brain as well as overproliferation of all glial cells. ${ }^{12}$ These occurred in mice that were exposed to $2.5 \mathrm{mg} / \mathrm{kg}, 5 \mathrm{mg} / \mathrm{kg}$, and $10 \mathrm{mg} / \mathrm{kg}$ body weight $\mathrm{TiO}_{2} \mathrm{NPs}$ through nasal administration for 90 days. The toxicokinetics (Figure 1) and toxic effects of 
$\mathrm{TiO}_{2} \mathrm{NPs}^{13-15}$ alone have been well documented in many in vivo and in vitro studies, but reviews of the effects (or toxicities) of the interaction of $\mathrm{TiO}_{2}$ NPs with other chemicals or physical factors are currently unavailable. $\mathrm{TiO}_{2} \mathrm{NPs}$ may coexist with other chemicals or physical factors in the surrounding environment and occupational settings. In the field of nanomedicine, $\mathrm{TiO}_{2}$ NPs are being used as drug carriers. ${ }^{3}$ Therefore, evaluating the interactive effects of $\mathrm{TiO}_{2} \mathrm{NPs}$ with other chemicals or physical factors is vital for the safe application of $\mathrm{TiO}_{2}$ NPs. This review will mainly focus on the current knowledge concerning the effects of the interaction of $\mathrm{TiO}_{2}$ NPs with other chemicals or physical factors and will identify areas where further improvement is needed.

\section{Effects of $\mathrm{TiO}_{2} \mathrm{NP}$ interaction with metals and their compounds}

With growing applications, $\mathrm{TiO}_{2}$ NPs are rapidly entering the aquatic environment, ${ }^{16}$ and thus the aquatic environment is expected ultimately to be a sink for the sedimentation of these NPs. Consequently, these NPs will inevitably mix and interact with other aquatic pollutants, including metals and their compounds. ${ }^{17}$ In addition, NPs have been found to be capable of absorbing and separating metals from aqueous or organic solutions. ${ }^{18,19}$

$\mathrm{TiO}_{2}$ NPs have been tested as a sorbent in the solid-phase extraction for preconcentrated lead $(\mathrm{Pb})$ in river water and seawater. ${ }^{20-22}$ Zhang et $\mathrm{al}^{20}$ investigated the potential acute toxicity of the interaction between $\mathrm{TiO}_{2} \mathrm{NPs}(50 \mathrm{~nm}$ and $120 \mathrm{~nm})$ and lead acetate $(\mathrm{PbAC})$ in mice. Suspensions of TiO ${ }_{2} \mathrm{NPs}(5 \mathrm{~g} / \mathrm{kg}$ body weight) alone, $\mathrm{PbAC}\left(500 \mathrm{mg} / \mathrm{kg}\right.$ ) alone, and $\mathrm{TiO}_{2} \mathrm{NPs}$ $(5 \mathrm{~g} / \mathrm{kg})$ plus PbAC (500 mg/kg) were administered to mice via oral gavage, respectively. No synergistic acute toxicity in mice was found after treatment with the combination of $\mathrm{TiO}_{2}$ NPs and PbAC. However, Du et $\mathrm{al}^{23}$ found that, compared with the control ( $1 \%$ dimethyl sulfoxide), mixtures of $\mathrm{TiO}_{2} \mathrm{NPs}_{\mathrm{s}}$ different doses (21 nm, 80\% anatase, 20\% rutile) plus PbAC $(1 \mu \mathrm{g} / \mathrm{mL})$ induced a significant increase in reactive oxygen species (ROS) generation (at $0.001 \mu \mathrm{g} / \mathrm{mL}, 0.01 \mu \mathrm{g} / \mathrm{mL}$, $0.1 \mu \mathrm{g} / \mathrm{mL}, 1 \mu \mathrm{g} / \mathrm{mL}$, and $10 \mu \mathrm{g} / \mathrm{mL}$ of $\mathrm{TiO}_{2}$ ), intracellular superoxide dismutase (SOD) activity (at $0.1 \mu \mathrm{g} / \mathrm{mL}$ and

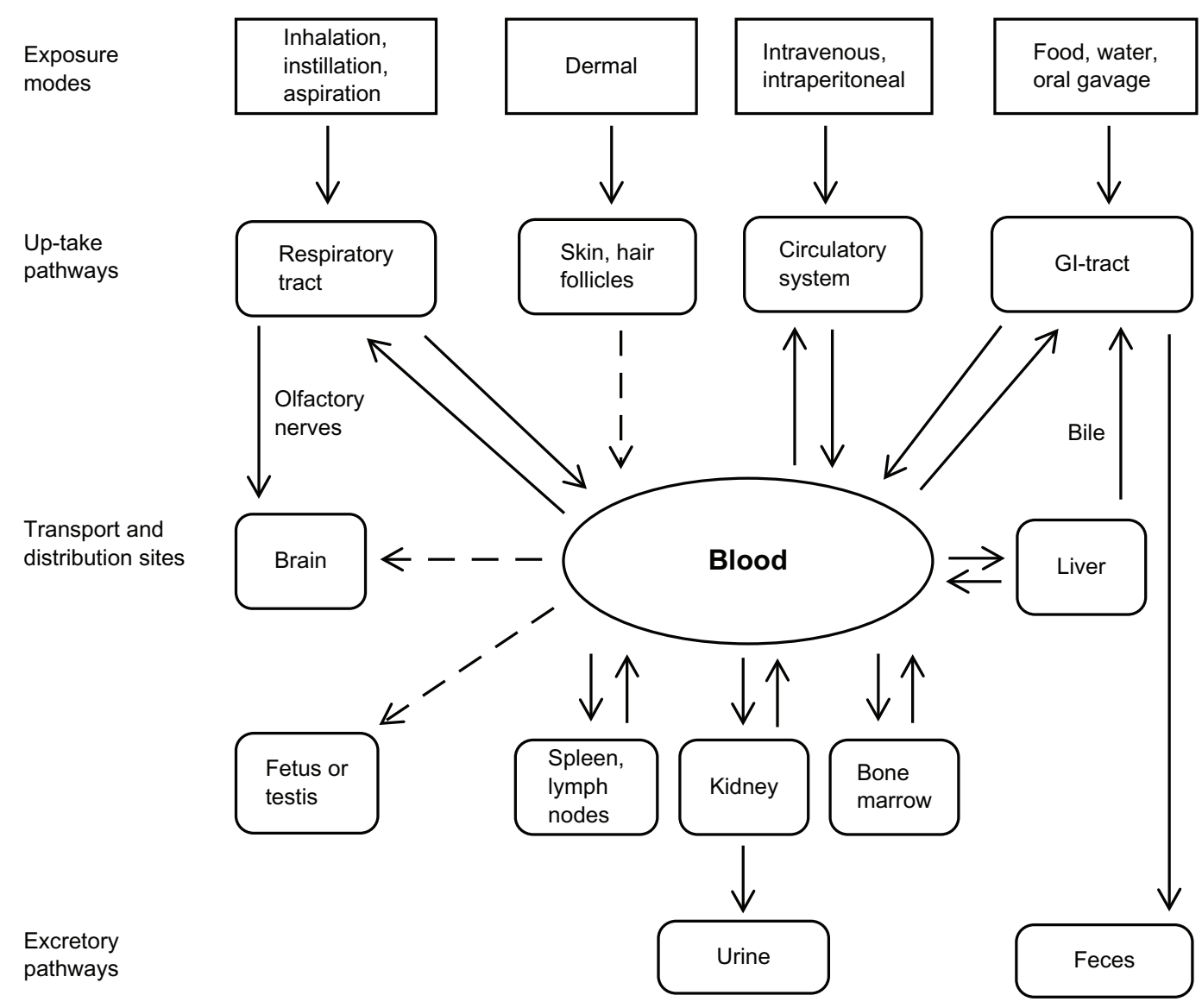

Figure I Toxicokinetics and accumulation sites of titanium dioxide nanoparticles.

Note: Reprinted from Shi et al, ${ }^{13}$ Copyright 2013, with permission from BioMed Central Publishing.

Abbreviation: $\mathrm{Gl}$, gastrointestinal. 
$0.01 \mu \mathrm{g} / \mathrm{mL}$ of $\mathrm{TiO}_{2}$ ), glutathione (GSH) levels (at $0.01-1 \mu \mathrm{g} /$ $\mathrm{mL}$ of $\mathrm{TiO}_{2}$ ), 8 -hydroxydeoxyguanosine levels (at $1 \mu \mathrm{g} / \mathrm{mL}$ and $10 \mu \mathrm{g} / \mathrm{mL}$ of $\mathrm{TiO}_{2}$ ), 8-oxoguanine DNA glycosylase homologue 1 expression (at $0.001-1 \mu \mathrm{g} / \mathrm{mL}$ of $\mathrm{TiO}_{2}$ ), and cytotoxicity (at $0.1 \mu \mathrm{g} / \mathrm{mL}, 1 \mu \mathrm{g} / \mathrm{mL}$, and $10 \mu \mathrm{g} / \mathrm{mL}$ of $\mathrm{TiO}_{2}$ ) in human embryo hepatocyte cells. These results suggest that interaction of $\mathrm{TiO}_{2} \mathrm{NPs}$ and $\mathrm{PbAC}$ may result in an increase of oxidative stress in culture cells.

Arsenic (As) is a metalloid. Chronic As exposure could cause cancer, neuropathies, and bronchopulmonary, cardiovascular, and metabolic diseases. ${ }^{24}$ To reduce As pollution, $\mathrm{TiO}_{2}$ NPs have been used as photocatalytic oxidants and/ or absorption materials to remove As from water, ${ }^{25}$ which implies an interaction between $\mathrm{As}$ and $\mathrm{TiO}_{2} \mathrm{NPs}$. Due to their small diameter, large surface area, and the ability to uptake $-\mathrm{OH}$ ions from solution, $\mathrm{TiO}_{2} \mathrm{NPs}$ could adsorb metal ions through electrostatic interaction. ${ }^{26,27}$ Evidence shows that variables such as $\mathrm{pH}$ and temperature may affect the absorption and/or desorption of As (III) and As (V) by $\mathrm{TiO}_{2} \mathrm{NPs}$ in the aqueous solution. Pena et $\mathrm{al}^{28}$ found that at $21^{\circ} \mathrm{C}-25^{\circ} \mathrm{C}$ and $\mathrm{pH}<8, \mathrm{TiO}_{2}$ NPs could be used to remove As $(\mathrm{V})$ from solution through adsorption, but the maximum removal for As (III) occurred at about pH 7.5. Additionally, they demonstrated that the competing anions such as silicate, carbonate, and phosphate had a low effect on the adsorption capacities of $\mathrm{TiO}_{2}$ NPs on As (III) and As (V) in a neutral $\mathrm{pH}$ range, which was in agreement with the results of Bang et al. ${ }^{29}$ Niu et al found that the adsorption of As (V) was more favored in acid solution at $25^{\circ} \mathrm{C}$, whereas the uptake of As (III) was preferred in alkaline solution by $\mathrm{TiO}_{2} \mathrm{NPs}$ at $25^{\circ} \mathrm{C} .{ }^{30}$ The maximum uptake of As (V) and As (III) was $208 \mathrm{mg} / \mathrm{g}$ $(\mathrm{pH}=3.0)$ and $60 \mathrm{mg} / \mathrm{g}(\mathrm{pH}=7.0)$. Their experiments also suggested that more than $80 \%$ of As (III) and $95 \%$ of As (V) adsorbed on $\mathrm{TiO}_{2}$ NPs could be desorbed with $1.0 \mathrm{M}$ sodium hydroxide solution within 1 hour, as demonstrated by desorption tests, which was confirmed by Bang et al. ${ }^{29}$ Jegadeesan et $\mathrm{al}^{31}$ indicated that the capacity for sorption to As by $\mathrm{TiO}_{2} \mathrm{NP}$ polymorphs might be affected by sorption site density, surface area (particle size), and crystalline structure. Wang et $\mathrm{al}^{32}$ stated that As toxicity on Ceriodaphnia dubia might increase when $\mathrm{TiO}_{2} \mathrm{NPs}(5-10 \mathrm{~nm})$ interact with As in the ecosystem. They found that $\mathrm{TiO}_{2} \mathrm{NPs}_{\text {less }}$ than $400 \mathrm{mg} / \mathrm{L}$ alone were nontoxic. The 24-hour median lethal concentration $\left(\mathrm{LC}_{50}\right)$ of As alone on Ceriodaphnia dubia was $3.68 \pm 0.22 \mathrm{mg} / \mathrm{L}$. In addition, the presence of low concentrations of $50 \mathrm{mg} / \mathrm{L} \mathrm{TiO}_{2}$ NPs increased the toxicity of As significantly, and the $\mathrm{LC}_{50}$ of As was also lowered to $1.43 \mathrm{mg} / \mathrm{L}$. In summary, available studies show that $\mathrm{pH}$, temperature, composite method, and crystalline structure may all be important for the adsorption of As (III) and As (V) by $\mathrm{TiO}_{2} \mathrm{NPs}$, and an alkaline environment is suitable for the desorption of As (III) and As (V). More studies are needed to investigate the toxicity effects after combination of As with $\mathrm{TiO}_{2} \mathrm{NPs}$.

Copper $(\mathrm{Cu})$ is an important element in human physiological processes. Exposure to low doses of $\mathrm{Cu}^{33}$ is harmless because $\mathrm{Cu}$ is an essential trace element for the human body. Adverse immunotoxicological effects on human health could be caused only by an overexposure to $\mathrm{Cu}$. Overexposure, especially a sublethal dose exposure of $\mathrm{Cu}$, could induce immunotoxicity in mice, including cell-cycle arrest and cell death in the spleen and thymus. ${ }^{34}$ Fan et $a l^{35}$ found that $\mathrm{TiO}_{2}$ NPs (at a concentration generally considered to be safe in the environment) remarkably enhanced the toxicity of $\mathrm{Cu}$ on Daphnia magna by increasing the bioaccumulation of $\mathrm{Cu}$. In addition, they found that the $\mathrm{Cu}$ was adsorbed on to the $\mathrm{TiO}_{2}$ NPs when ingested and was accumulated in the animals, thereby causing an increase in toxic effects.

Cadmium $(\mathrm{Cd})$ is one of the most toxic elements to which human beings may be exposed. ${ }^{36-38} \mathrm{Cd}$ compounds ${ }^{39}$ are widely used in rechargeable nickel-Cd batteries. Cigarette smoke, polluted foods, and batteries are the major sources of $\mathrm{Cd}$ pollution. Xia et $\mathrm{al}^{40}$ investigated the combined toxicity of cadmium chloride $\left(\mathrm{CdCl}_{2}\right)$ and $\mathrm{TiO}_{2} \mathrm{NPs}(25 \mathrm{~nm})$ in human embryo kidney (HEK293T) cells. They found that cotreatment with $3.8 \mu \mathrm{m} / \mathrm{L} \mathrm{CdCl}_{2}$ and $7.5 \mu \mathrm{g} / \mathrm{mL} \mathrm{TiO}_{2} \mathrm{NPs}$ exerted additive effects on the cellular oxidative damage by upregulation of heme oxygenase 1 gene expression, catalase activities, and malondialdehyde concentration. A combination of $\mathrm{CdCl}_{2}(5.12 \mu \mathrm{m} / \mathrm{L})$ and $\mathrm{TiO}_{2}$ NPs $(10.05 \mu \mathrm{g} / \mathrm{mL})$ showed synergetic effects on activities of SOD and ROS concentrations. Zhang et $\mathrm{a}^{41}$ assessed the bioaccumulation of $\mathrm{Cd}$ in carp in the presence of $\mathrm{TiO}_{2} \mathrm{NPs}(21 \mathrm{~nm})$ and found that the presence of $\mathrm{TiO}_{2} \mathrm{NPs}$ and the accumulation of $\mathrm{Cd}$ in carp was positively correlated.

$\mathrm{Hu}$ et $\mathrm{al}^{42}$ investigated the combined effects of $\mathrm{TiO}_{2} \mathrm{NPs}$ $(21 \mathrm{~nm})$ and humic acid (HA) on the bioaccumulation of $\mathrm{Cd}$ in zebrafish. They found that the presence of $\mathrm{TiO}_{2} \mathrm{NPs}$ at $5-20 \mathrm{mg} / \mathrm{L}$ in water containing HA could alter the exposure of $\mathrm{Cd}$ and other potential heavy metals to zebrafish. The presence of $\mathrm{TiO}_{2} \mathrm{NPs}$ or HA alone with Cd slightly increased the uptake rate constants of $\mathrm{Cd}$ in fish. $\mathrm{TiO}_{2} \mathrm{NPs}$ have a slightly higher uptake than HA, whereas mixtures of $\mathrm{HA}$ and $\mathrm{TiO}_{2} \mathrm{NPs}$ with $\mathrm{Cd}$ slightly reduced the uptake rate constants. The mechanism underlying these combined effects is unclear. 
Yang et $\mathrm{al}^{43}$ investigated $\mathrm{Cd}$ adsorption on polyacrylatecoated $\mathrm{TiO}_{2} \mathrm{NPs}$, which could decrease the concentration of $\mathrm{Cd}$ ion in an aquatic environment and its effect on the bioavailability as well as toxicity of $\mathrm{Cd}$ to green algae Chlamydomonas reinhardtii. They found that $\mathrm{Cd}$ absorbed quickly on to $\mathrm{TiO}_{2} \mathrm{NPs}$ (anatase, $1-10 \mathrm{~nm}$ ), reaching a steady state within 30 minutes. Interestingly, they found that the presence of $\mathrm{TiO}_{2} \mathrm{NPs}$ could alleviate the $\mathrm{Cd}$ toxicity to the green algae cells, which might be caused by $\mathrm{TiO}_{2} \mathrm{NP}$ adsorption on $\mathrm{Cd}^{2+}$, resulting in a decrease of free $\mathrm{Cd}$ ion in the medium and, further, its bioaccumulation in the algal cells. In addition, the electrostatic and potentially steric repulsions between $\mathrm{TiO}_{2}$ NPs and algal cells might hinder their direct contact with each other and then prevent the internalization of $\mathrm{TiO}_{2}$ NPs into the cells.

Taken together, toxicities of $\mathrm{TiO}_{2} \mathrm{NPs}$ alone have been well documented. ${ }^{10,44,45}$ However, knowledge of the combined effects of $\mathrm{TiO}_{2} \mathrm{NPs}$ with other chemicals is limited. The existing evidence suggests that $\mathrm{TiO}_{2} \mathrm{NPs}$ can absorb metal ions, including $\mathrm{Pb}, \mathrm{As}, \mathrm{Cu}$, and $\mathrm{Cd}$, in the solution. Meanwhile, interaction of $\mathrm{TiO}_{2} \mathrm{NPs}$ and metal compounds (see Table 1) may also result in the increased toxicity demonstrated by increased oxidative stress to cells and decreased $\mathrm{LC}_{50}$ to aquatic organisms. ${ }^{23,40}$ Therefore, more ecology investigations and biology experiments of their combined toxicity should be carried out.

\section{Effects of $\mathrm{TiO}_{2}$ NP interaction with organic and inorganic compounds}

Bisphenol A (BPA) is an endocrine disruptor that can mimic estrogen and may lead to adverse health effects..$^{46,47}$ Woodruff et $\mathrm{al}^{48}$ analyzed data for 163 chemical analytes in 12 chemical classes in subsamples of 268 pregnant women from the National Health and Nutrition Examination Survey

Table I Studies in vitro on the interactive effects of $\mathrm{TiO}_{2} \mathrm{NPs}$ with chemicals or physical factors

\begin{tabular}{|c|c|c|c|c|c|c|}
\hline \multirow[t]{2}{*}{ Reference } & \multirow[t]{2}{*}{ Supplier } & \multicolumn{3}{|c|}{ Characteristics of $\mathrm{TiO}_{2} \mathrm{NP}$} & \multirow[t]{2}{*}{ Dispersion method } & \multirow{2}{*}{$\begin{array}{l}\text { Exposure } \\
\text { concentration }(\mu \mathrm{g} / \mathrm{mL})\end{array}$} \\
\hline & & $\begin{array}{l}\text { Particle } \\
\text { size }(\mathbf{n m})\end{array}$ & $\begin{array}{l}\text { Crystal } \\
\text { structure }\end{array}$ & $\begin{array}{l}\text { Surface } \\
\text { area }\left(\mathrm{m}^{2} / g\right)\end{array}$ & & \\
\hline 23 & Degussa & 21 & $\begin{array}{l}80 \% \text { anatase, } \\
20 \% \text { rutile }\end{array}$ & 49.6 & $\begin{array}{l}10 \text { min ultrasonication } \\
\text { and } 30 \mathrm{~s} \text { vortex mixing }\end{array}$ & $0.001,0.01,0.1, I, 10$ \\
\hline 40 & Degussa & 25 & $\begin{array}{l}80 \% \text { anatase, } \\
20 \% \text { rutile }\end{array}$ & 50 & $\begin{array}{l}\text { Suspended fresh } \\
\text { immediately before } \\
\text { use }\end{array}$ & $\begin{array}{l}0,0.25,0.5,0.75 \\
\text { I, I.25 TU } \\
(\mathrm{ITU}=10.05 \mu \mathrm{g} / \mathrm{mL})\end{array}$ \\
\hline 49 & Degussa & $25-50$ & $\begin{array}{l}80 \% \text { anatase, } \\
20 \% \text { rutile }\end{array}$ & 50 & $\begin{array}{l}\text { Vortexed for } 2 \mathrm{~min} \text {, } \\
\text { ultrasonicated for } 10 \mathrm{~min}\end{array}$ & $0,1,5,10$ \\
\hline 55 & Degussa & 25 & $\begin{array}{l}80 \% \text { anatase, } \\
20 \% \text { rutile }\end{array}$ & 50 & NA & $0,0.01,0.1,1$ \\
\hline 57 & Degussa & 21 & $\begin{array}{l}80 \% \text { anatase, } \\
20 \% \text { rutile }\end{array}$ & NA & Ultrasonicated for $40 \mathrm{~min}$ & 0,10 \\
\hline 65 & Degussa & 20 & $\begin{array}{l}\text { rutile and } \\
\text { anatase }\end{array}$ & 50 & Ultrasonicated for $15 \mathrm{~min}$ & 50 \\
\hline 66 & $\begin{array}{l}\text { Wanjin Material } \\
\text { Corp; Degussa }\end{array}$ & $\begin{array}{l}4,10,2125 \\
\text { or } 60\end{array}$ & $\begin{array}{l}\text { anatase, rutile; } \\
\text { anatase/rutile }(3: I)\end{array}$ & NA & $\begin{array}{l}\text { Freshly prepared } \\
\text { and diluted }\end{array}$ & $0,10,50,100,200$ \\
\hline 67 & Degussa & 20 & $\begin{array}{l}70 \%-85 \% \text { anatase } \\
\text { and } 30 \%-15 \% \text { rutile }\end{array}$ & 48.08 & Sonicated for $30 \mathrm{~min}$ & $0,1,5$ \\
\hline 68 & $\begin{array}{l}\text { Sigma Chemicals, } \\
\text { Degussa }\end{array}$ & $\begin{array}{l}<25 \\
<100 ; 31\end{array}$ & $\begin{array}{l}\text { anatase, rutile; } 86 \% \\
\text { anatase, } 14 \% \text { rutile }\end{array}$ & NA & Sonicated for $30 \mathrm{~min}$ & 50,100 \\
\hline 71 & Degussa & 21 & $\begin{array}{l}25 \% \text { rutile and } \\
75 \% \text { anatase }\end{array}$ & NA & Sonicated for $10-15 \mathrm{~min}$ & 200 \\
\hline 75 & Sigma-Aldrich & NA & anatase and rutile & NA & Sonicated for $30 \mathrm{~min}$ & 200 \\
\hline 82 & Degussa & NA & NA & NA & NA & 61,60 \\
\hline
\end{tabular}

Abbreviations: $\uparrow$, combined effect showed a significant increase than $\mathrm{TiO}_{2} \mathrm{NPs}$ group and other factor group alone; $\downarrow$, combined effect showed a significant decrease than $\mathrm{TiO}_{2} \mathrm{NPs}$ group and other factor group alone; $\leftrightarrow$, combined effect showed no significant difference than TiO $\mathrm{NPs}_{2}$ group and other factor group alone; 8-OHdG, 8-hydroxydeoxyguanosine; GSH, glutathione; HO-I gene, heme oxygenase I gene; MMP, mitochondrial membrane potential; NA, data not available; NPs, nanoparticles; OGG I, 8-oxoguanine DNA glycosylase homologue I; ROS, reactive oxygen species; SOD, superoxide dismutase; TiO ${ }_{2}$, titanium dioxide; UVA, ultraviolet A ; DNA, deoxyriboNucleic acid; MDA, malondialdehyde; CAT, catalase activities; NO, nitric oxide; PARP, poly (ADP-ribose) polymerase ; MTS, 3-(4,5-dimethylthiazol-2-yl)-5-(3-carboxymethoxyphenyl)2-(4-sulfophenyl)-2H-tetrazolium; NAC, N-acetyl cysteine; LDH, lactic acid dehydrogenase; mRNA, messenger ribonucleic acid; BAX, Bcl-2-associated X protein; DMEM, Dulbecco's Modified Eagle's Medium; TU, toxic unit; MEM, Minimum Essential Medium; ADP, adenosine diphosphate; min, minutes; PbAC, Plumbi Acetatis; BPA, bisphenol A; $\mathrm{HBE}$, human bronchial epithelial cell; NaF, sodium fluoride; h, hours; $\mathrm{HaCaT}$, a cell type belonging to an immortal human keratinocyte line; RPMI, Roswell Park Memorial Institute; BCL2, B-cell lymphoma 2 protein. 
2003-04, a nationally representative sample of the US population. They found that BPA was detectable in $96 \%$ of pregnant women. Therefore, interactions between $\mathrm{TiO}_{2}$ NPs and BPA may occur when $\mathrm{TiO}_{2}$ NPs are used as drug carriers in the human body. Zheng et $\mathrm{al}^{49}$ evaluated the interactive effects of $\mathrm{TiO}_{2}$ NPs $(25-50 \mathrm{~nm})$ with BPA on their physiochemical properties and in vitro toxicity in human embryo hepatocytes (L-02 cells). They found that $\mathrm{TiO}_{2} \mathrm{NPs}$ alone $(0 \mathrm{mg} / \mathrm{L}, 0.1 \mathrm{mg} / \mathrm{L}, 1 \mathrm{mg} / \mathrm{L}$, and $10 \mathrm{mg} / \mathrm{L})$ or BPA alone $(0 \mu \mathrm{mol} / \mathrm{L}, 0.1 \mu \mathrm{mol} / \mathrm{L}, 1 \mu \mathrm{mol} / \mathrm{L}$, and $10 \mu \mathrm{mol} / \mathrm{L})$ did not exert significant DNA and chromosomal damage, whereas the mixture of $\mathrm{TiO}_{2}$ NPs and BPA induced a significant increase in oxidative stress, DNA double-strand breaks, and micronuclei formation in a weak synergistic manner. An increase in intracellular levels of BPA bound by $\mathrm{TiO}_{2}$ NPs was hypothesized to be the reason behind the synergistic toxicity. This could have been determined if the investigators in this study used varying concentrations of $\mathrm{TiO}_{2}$ NPs in the combination.

Dichlorodiphenyltrichloroethane ( $\mathrm{p}, \mathrm{p}^{\prime}$-DDT) was widely used as an effective insecticide, and had been proven to have genotoxicity, developmental toxicity, and endocrinedisruptive effects in human beings and a wide range of living organisms. ${ }^{50-52}$ Therefore, the degradation of DDT had attracted great attention. ${ }^{53,54}$ Recently, $\mathrm{TiO}_{2}$ NPs have been tested to degrade the $\mathrm{p}, \mathrm{p}^{\prime}$-DDT, which increases the risk of exposure to mixtures of $\mathrm{TiO}_{2} \mathrm{NPs}$ and $\mathrm{p}, \mathrm{p}^{\prime}$-DDT. Shi et al ${ }^{55}$ examined the interactive toxicities of $\mathrm{p}, \mathrm{p}^{\prime}-\mathrm{DDT}$ and $\mathrm{TiO}_{2} \mathrm{NPs}$ $(25 \mathrm{~nm})$ at low concentrations in L-02 cells. The mixtures induced higher toxicity than $\mathrm{TiO}_{2} \mathrm{NPs}$ or $\mathrm{p}, \mathrm{p}^{\prime}$-DDT alone. Combination of traces of $\mathrm{TiO}_{2}$ NPs $(0 \mu \mathrm{g} / \mathrm{mL}, 0.01 \mu \mathrm{g} / \mathrm{mL}$, $0.1 \mu \mathrm{g} / \mathrm{mL}$, and $1 \mu \mathrm{g} / \mathrm{mL})$ and traces of p, $\mathrm{p}^{\prime}$-DDT $(0 \mu \mathrm{mol} / \mathrm{L}$, $0.001 \mu \mathrm{mol} / \mathrm{L}, 0.01 \mu \mathrm{mol} / \mathrm{L}$, and $0.1 \mu \mathrm{mol} / \mathrm{L})$ synergistically enhanced genotoxicity, as demonstrated by an increase in

\begin{tabular}{|c|c|c|c|c|}
\hline $\begin{array}{l}\text { Exposure } \\
\text { time }\end{array}$ & Cell line & $\begin{array}{l}\text { Culture } \\
\text { medium }\end{array}$ & $\begin{array}{l}\text { Combined factors/exposure } \\
\text { condition }\end{array}$ & Combined effects \\
\hline $24 \mathrm{~h}$ & L-02 & DMEM & $\mathrm{PbAC} / \mathrm{I} \mu \mathrm{g} / \mathrm{mL}$ & 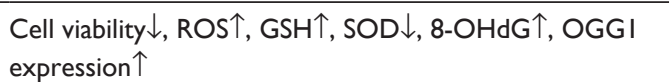 \\
\hline $24 \mathrm{~h}$ & HEK293T & DMEM & $\begin{array}{l}\mathrm{CdCl}_{2} / 0,0.25,0.5,0.75 \\
\mathrm{I}, \mathrm{I} .25 \mathrm{TU}(\mathrm{I} \mathrm{TU}=5.12 \mu \mathrm{mol} / \mathrm{L})\end{array}$ & $\begin{array}{l}\text { HO-I gene express } \uparrow, \text { OGGI expression } \uparrow, \text { SOD } \downarrow, \text { ROS } \uparrow, \\
\text { MDA } \leftrightarrow, \text { CAT } \uparrow\end{array}$ \\
\hline $24 \mathrm{~h}$ & $\mathrm{~L}-02$ & DMEM & $\mathrm{BPA} / 0,0.1, \mathrm{I}, 10 \mu \mathrm{mol} / \mathrm{L}$ & $\begin{array}{l}\text { Cell viability } \leftrightarrow, \operatorname{ROS} \uparrow, \text { MDA } \uparrow, \text { DNA double strand break } \uparrow, \\
\text { chromosomal damage } \uparrow\end{array}$ \\
\hline $\begin{array}{l}12,24 \\
36 \mathrm{~h}\end{array}$ & $\mathrm{~L}-02$ & DMEM & $\begin{array}{l}\mathrm{P}, \mathrm{p}^{\prime}-\mathrm{DDT} / 0,0.00 \mathrm{I}, 0.0 \mathrm{I} \\
\text { and } 0.1 \mu \mathrm{mol} / \mathrm{L}\end{array}$ & $\begin{array}{l}\text { Cell viability } \leftrightarrow \text {, apoptosis test } \leftrightarrow, \text { ROS } \uparrow, \text { MDA } \uparrow, 8-O H d G \uparrow ; \\
\text { DNA strand break } \uparrow ; \text { micronucleus frequency } \uparrow\end{array}$ \\
\hline $72 \mathrm{~h}$ & I6-HBE & RPMI- 1640 & $\mathrm{NaF} / 0,10,20,30 \mathrm{mg} / \mathrm{L}$ & Cell viability $\leftrightarrow$, apoptosis test $\uparrow$, SOD $\downarrow$, MDA $\uparrow$, NO $\uparrow$ \\
\hline I h & $\mathrm{HaCaT}$ & NA & $\begin{array}{l}\text { Nitrite, UVA/nitrite: 0, 0.I, 0.5, } \\
\text { I, } 2 \mathrm{mM} \text {; UVA: } 365 \mathrm{~nm} \text {, } \\
0.6 \mathrm{~mW} / \mathrm{cm}^{2}, \mathrm{I} \mathrm{h}\end{array}$ & Cell viability $\downarrow$, apoptosis test $\uparrow$, protein tyrosine nitration $\uparrow$ \\
\hline I h & $\mathrm{HaCaT}$ & MEM & UVA/365 nm, $3.5 \mathrm{~mW} / \mathrm{cm}^{2}, \mathrm{I} \mathrm{h}$ & Cell viability $\downarrow$, SOD $\downarrow$, ROS $\uparrow$, MDA $\uparrow$ \\
\hline $\begin{array}{l}0,24 \\
48 \mathrm{~h}\end{array}$ & $\begin{array}{l}\text { Human } \\
\text { peripheral blood } \\
\text { lymphocytes }\end{array}$ & RPMI- 1640 & $\begin{array}{l}\text { UVA/365 nm, } 2.0 \mathrm{~mW} / \mathrm{cm}^{2} \\
0,24,48 \mathrm{~h}\end{array}$ & $\begin{array}{l}\text { Cell viability } \downarrow \text {, sub-GI phase } \uparrow \text {, caspase-9 } 9 \text {, caspase- } 3 \uparrow \text {, } \\
\text { and PARP } \uparrow M P \downarrow \text { MOS R RNA damage } \uparrow \text { micronucleus } \\
\text { formation } \uparrow\end{array}$ \\
\hline $4 \mathrm{~h}$ & $\mathrm{HaCaT}$ & DMEM & $\begin{array}{l}\text { UVA } / 320-390 \mathrm{~nm} ; 0,2.5,5.0 \\
\text { and } 10 \mathrm{~J} / \mathrm{cm}^{2}\end{array}$ & MTS assay (A325, P25 and A25) $\downarrow$, ROS $\uparrow$ \\
\hline $24 \mathrm{~h}$ & $\mathrm{HaCaT}$ & MEM & $\begin{array}{l}\text { NAC, UVA/NAC: } 5 \mathrm{mM}, 2 \text { h UVA: } \\
365 \mathrm{~nm}, 3.5 \mathrm{~W} / \mathrm{cm}^{2}, \mathrm{I} \mathrm{h}\end{array}$ & $\begin{array}{l}\text { Cell viability (UVA) } \downarrow(\text { UVA + NAC) } \uparrow, \text { LDH (UVA+NAC) } \downarrow \text {, } \\
\text { apoptosis assay (UVA + NAC) } \downarrow, \text { ROS (UVA + NAC) } \downarrow, \\
\text { MMP (UVA + NAC) } \uparrow, \text { K6 mRNA (UVA + NAC) } \uparrow\end{array}$ \\
\hline $12 \mathrm{~h}$ & U87-MG & DMEM & UVA/365 nm, $5 \mathrm{~J} / \mathrm{cm}^{2}, 20 \mathrm{~min}$ & Cell viability $\downarrow, B C L 2 \downarrow, B A X \uparrow$ \\
\hline $10 \min$ & Leukemia K562 & RPMI- 1640 & $\begin{array}{l}\text { Daunorubicin, UVA/daunorubicin: } \\
0.14 \mathrm{mM}, 0.2 \mathrm{mM} \text { UVA: } 100 \mathrm{~s}\end{array}$ & Drug accumulation $\uparrow$ \\
\hline
\end{tabular}


oxidative stress, oxidative DNA adducts, DNA breaks, and chromosomal damage in L-02 cells. The adsorption of $\mathrm{p}, \mathrm{p}^{\prime}-$ DDT by $\mathrm{TiO}_{2} \mathrm{NPs}_{\mathrm{s}}$ was approximately $0.3 \mathrm{mmol} / \mathrm{g}$. Synergistic genotoxicity induced by a combination of traces of $\mathrm{p}, \mathrm{p}^{\prime}$-DDT and $\mathrm{TiO}_{2}$ NPs may be a potential environmental risk factor. Sodium fluoride $(\mathrm{NaF})$ and $\mathrm{TiO}_{2}$ NPs are useful additives in household products such as toothpastes. ${ }^{3,56} \mathrm{Xie}$ et $\mathrm{al}^{57}$ examined the combined effects of $\mathrm{NaF}$ and $\mathrm{TiO}_{2} \mathrm{NPs}(21 \mathrm{~nm})$ in human bronchial epithelial cells (16-HBE) and found that combined exposure of $\mathrm{NaF}$ and $\mathrm{TiO}_{2} \mathrm{NPs}$ could enhance the oxidative stress in 16-HBE cells. In another study, Xu et $\mathrm{al}^{58}$ investigated the interactions of $\mathrm{TiO}_{2}$ NPs with functional biomolecule lysozymes in culture cells. They found that lysozymes were adsorbed on to the surface of $\mathrm{TiO}_{2} \mathrm{NPs}$ $(60 \mathrm{~nm})$ via electrostatic attraction and hydrogen bonds. They therefore suggested that $\mathrm{TiO}_{2}$ NPs might have some toxic impacts on biomolecules after interacting with biomolecule lysozymes. In summary, studies on the effects of $\mathrm{TiO}_{2} \mathrm{NP}$ interaction with organic or inorganic compounds are limited. The existing evidence indicates that interaction of $\mathrm{TiO}_{2} \mathrm{NPs}$ with BPA, p,p'-DDT, or NaF may result in enhancement of oxidative stress and further cyto or ecotoxicity.

\section{Effects of $\mathrm{TiO}_{2}$ NP interaction with the physical factor UVA}

$\mathrm{TiO}_{2}$ NPs possess excellent optical and electrical properties. ${ }^{59-61}$ Due to photocatalysis, $\mathrm{TiO}_{2} \mathrm{NPs}^{62,63}$ are used to degrade formaldehyde and thus improve air quality in the indoor environment. However, some studies suggest that $\mathrm{TiO}_{2}$ NPs might be toxic under ultraviolet A (UVA), an electromagnetic radiation with wavelength range from $315 \mathrm{~nm}$ to $400 \mathrm{~nm}$, ISO-21348. Lu et al ${ }^{64}$ found that $\mathrm{TiO}_{2} \mathrm{NPs}$ $(20 \mathrm{~nm})$ could induce photocatalytic nitration of the protein tyrosine, which could lead to prevalent post-translational modification by $\mathrm{TiO}_{2}$ NPs as a result of oxidative and nitrative stress. In another study, $\mathrm{Tu}$ et $\mathrm{al}^{65}$ found that nitrative stress induced by $\mathrm{TiO}_{2}$ NPs $(20 \mathrm{~nm})$ under UVA radiation triggered apoptotic cell death in human keratinocyte cells. This result suggests that skincare products with $\mathrm{TiO}_{2} \mathrm{NP}$ components may cause damage to human keratinocyte cells under UVA radiation. Xue et $\mathrm{al}^{66}$ investigated the oxidative stress and cytotoxicity induced by different crystalline forms (anatase, rutile, and anatase/rutile) and sizes (4 nm, $10 \mathrm{~nm}$, $21 \mathrm{~nm}, 25 \mathrm{~nm}$, or $60 \mathrm{~nm}$ ) of $\mathrm{TiO}_{2}$ NPs in HaCaT cells under UVA irradiation. They found that $\mathrm{TiO}_{2} \mathrm{NPs}$ could induce ROS generation and toxicity in cells under UVA irradiation. Kang et $\mathrm{al}^{67}$ also showed that $\mathrm{TiO}_{2}$ NPs $(20 \mathrm{~nm})$ and UVA $\left(0.6 \mathrm{~mW} / \mathrm{cm}^{2}\right.$ for 1 hour) synergistically promoted
ROS generation and triggered cell apoptosis. Yin et $\mathrm{al}^{68}$ examined the phototoxicity of $\mathrm{TiO}_{2}$ NPs with different sizes and crystal forms (anatase and rutile) in human skin keratinocytes under UVA irradiation. They found that $\mathrm{TiO}_{2}$ NPs are phototoxic to human skin keratinocytes, and that the phototoxicity is mediated by ROS generated during UVA radiation. Moreover, the phototoxicity of $\mathrm{TiO}_{2} \mathrm{NPs}_{\text {was less }}$ with larger particle size and surface areas. Zhang et al ${ }^{69}$ investigated the combined effects of $\mathrm{TiO}_{2}$ NPs and UVA exposure on African clawed frogs (Xenopus laevis). They found that, regardless of UVA exposure, the rate of $X$. laevis survival decreased with increased concentrations of $\mathrm{TiO}_{2}$ NPs. Exposure to $10 \mathrm{~nm} \mathrm{TiO} 2$ NPs and UVA significantly decreased the rate of $X$. laevis survival. However, exposure to $32 \mathrm{~nm} \mathrm{TiO}$ NPs and UVA had no statistical effect on the rate of $X$. laevis survival. This experiment suggests that toxicity is related to the size of $\mathrm{TiO}_{2}$ NPs to some extent. Bar-Ilan et $\mathrm{al}^{70}$ also found that $\mathrm{TiO}_{2} \mathrm{NPs}$ under UV produced ROS as the major phototoxic agent to the development of zebrafish. Xue et al ${ }^{71}$ examined the chemoprotective effects of $\mathrm{N}$-acetylcysteine (NAC) ( $5 \mathrm{mM}$ pretreated for 2 hours) on $\mathrm{TiO}_{2}$ NP-induced ( $21 \mathrm{~nm}, 200 \mu \mathrm{g} / \mathrm{mL}$ for 24 hours) oxidative stress and apoptosis in human keratinocytes under UVA (3.5 mW/ $\mathrm{cm}^{2}$ for 1 hour). NAC, ${ }^{72-74}$ a nutritional supplement for cysteine donating, is widely used as an antioxidant. They found that NAC could prevent $\mathrm{TiO}_{2} \mathrm{NP}$-induced oxidative stress and apoptosis in cells. The protective effects of NAC on $\mathrm{TiO}_{2} \mathrm{NP}$-induced apoptosis were related to modulation of ROS and intracellular nitric oxide levels. It is worth noting that the combined effect of $\mathrm{TiO}_{2}$ NPs and UVA may be a double-edged sword. Wang et $\mathrm{al}^{75}$ investigated the antitumor effects of $\mathrm{TiO}_{2}$ NPs excited with UVA irradiation both in vitro and in vivo. Their results revealed that $\mathrm{TiO}_{2} \mathrm{NPs}_{\text {alone }}$ had no effect on glioma cell proliferation. However, when $\mathrm{TiO}_{2}$ NPs were combined with UVA irradiation, the proliferation rate of cells was decreased significantly compared with controls $\left(\mathrm{TiO}_{2}\right.$ NPs alone or UVA alone). They further investigated the in vivo antitumor effects of combined $\mathrm{TiO}_{2}$ NPs plus UVA on established glioma tumors. $\mathrm{TiO}_{2} \mathrm{NPs}$ plus UVA led to pronounced areas of necrosis, elevated indices of apoptosis, delayed tumor growth, and increased survival compared with the $\mathrm{TiO}_{2}$ NPs alone or UVA alone. Moreover, the log-rank test for trend in survival analysis of tumors implanted in animals showed that the average survival duration was prolonged. Additionally, degradation, detoxification, and/or bactericidal effects of $\mathrm{TiO}_{2} \mathrm{NPs}_{\mathrm{s}}$ under UVA to some pesticides or drugs in the ecosystem have been widely investigated. ${ }^{76,77}$ Under UV-irradiated conditions 
$(\lambda>350 \mathrm{~nm})$, a $\mathrm{TiO}_{2}$ electron excites an electron from the valance band to the conduction band and electron hole pairs are generated in the surface of $\mathrm{TiO}_{2}$, which consists of the positive hole $\left(h^{+}\right)$and electron $\left(e^{-}\right)$. The hole in the valence band has a positive redox potential and is capable of oxidizing organics, $\mathrm{H}_{2} \mathrm{O}$, and hydroxide ions on the surface of $\mathrm{TiO}_{2} \mathrm{NPs}$, and eventually to generate hydroxyl radicals $(\mathrm{OH})$. At the same time, the electron promoted from the valence band to the conduction band reduces oxygen into a superoxide radical $\left(\mathrm{O}_{2}^{-}\right)$. OH, $\mathrm{O}_{2}^{-}$, and other perhydroxyl radicals have a strong oxidability to degradate pesticides, drugs, and organic substances (Figure 2). The photocatalytic effects of $\mathrm{TiO}_{2}$ NPs have been indicated to degrade pesticides such as endosulfan and organochlorine. ${ }^{78}$ Seitz et a $7^{79}$ found that $\mathrm{TiO}_{2} \mathrm{NPs}(\sim 100 \mathrm{~nm} ; 0.2 \mathrm{mg} / \mathrm{L})$ could reduce nearly $30 \%$ of the pirimicarb concentration under UV irradiation $\left(40 \mathrm{~W} / \mathrm{m}^{2}\right.$ for 15 minutes), which resulted in an almost complete removal of pirimicarb toxicity to D. magna. Zhao et $\mathrm{al}^{80}$ indicated that $\mathrm{TiO}_{2}$ NPs under UV irradiation could degrade oxytetracycline, which is widely used in both human and veterinary medicine. Higher degraded toxic byproducts were detected by a standardized bioluminescence assay of inhibition rate on Vibrio qinghaiensis sp.-Q67 (Q67), which indicates that a possible enhancement in ecological toxicity may occur after combination of $\mathrm{TiO}_{2} \mathrm{NPs}$ with oxytetracycline under UVA irradiation. These results indicate that the photocatalytic effect of $\mathrm{TiO}_{2} \mathrm{NPs}$ on pesticides and drugs under UVA irradiation may result in either increased or decreased toxicity, depending on the characteristics of the byproducts.

$\mathrm{Li}$ et a ${ }^{81}$ demonstrated that $\mathrm{Ag}-\mathrm{TiO}_{2} \mathrm{NPs}$ showed a greater synergistic bactericidal activity under $\mathrm{UV}$ than $\mathrm{TiO}_{2}$ (inert) or pure Ag NPs alone to Gram-positive bacteria Bacillus subtilis and Gram-negative bacteria Pseudomonas putida at $25^{\circ} \mathrm{C}$. Additionally, Song et al ${ }^{82}$ found that the synergistic effect of $\mathrm{TiO}_{2}$ NPs under UV irradiation could enhance the drug accumulation dose in targeted leukemia K562 cells and inhibit multidrug resistance. Their findings suggest that combined effects of $\mathrm{TiO}_{2}$ NPs and UVA irradiation may be beneficial

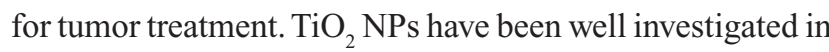
recent years for enhancing the photocatalytic activity, coating, and doping of zinc oxide $(\mathrm{ZnO})$ on to its surface ${ }^{83,84}$ Liao et $\mathrm{al}^{83}$ found that $\mathrm{TiO}_{2} / \mathrm{ZnO}$ composite NPs had a higher photocatalytic activity in the degradation of methyl orange than both $\mathrm{TiO}_{2}$ and shape-controlled NPs alone. Additionally, Jiang et a ${ }^{85}$ demonstrated that a combination of the nanosized $\mathrm{TiO}_{2}$ and $\mathrm{ZnO}$ powders displayed high photocatalytic activity toward the decolorization of C.I. Basic Blue 41 in water under solar radiation, and a Ti/Zn molar ratio of 1:1 showed highest photocatalytic activity.

In conclusion, $\mathrm{TiO}_{2} \mathrm{NPs}$ excited with UVA irradiation could induce ROS generation and thus trigger photocatalytic nitration of the protein tyrosine, oxidative stress, and eventually cell apoptosis. Increased oxidative stress damage may be the principal toxic mechanism. Combined toxicity of $\mathrm{TiO}_{2}$ NPs under UVA may be through ROS-mediated upregulation

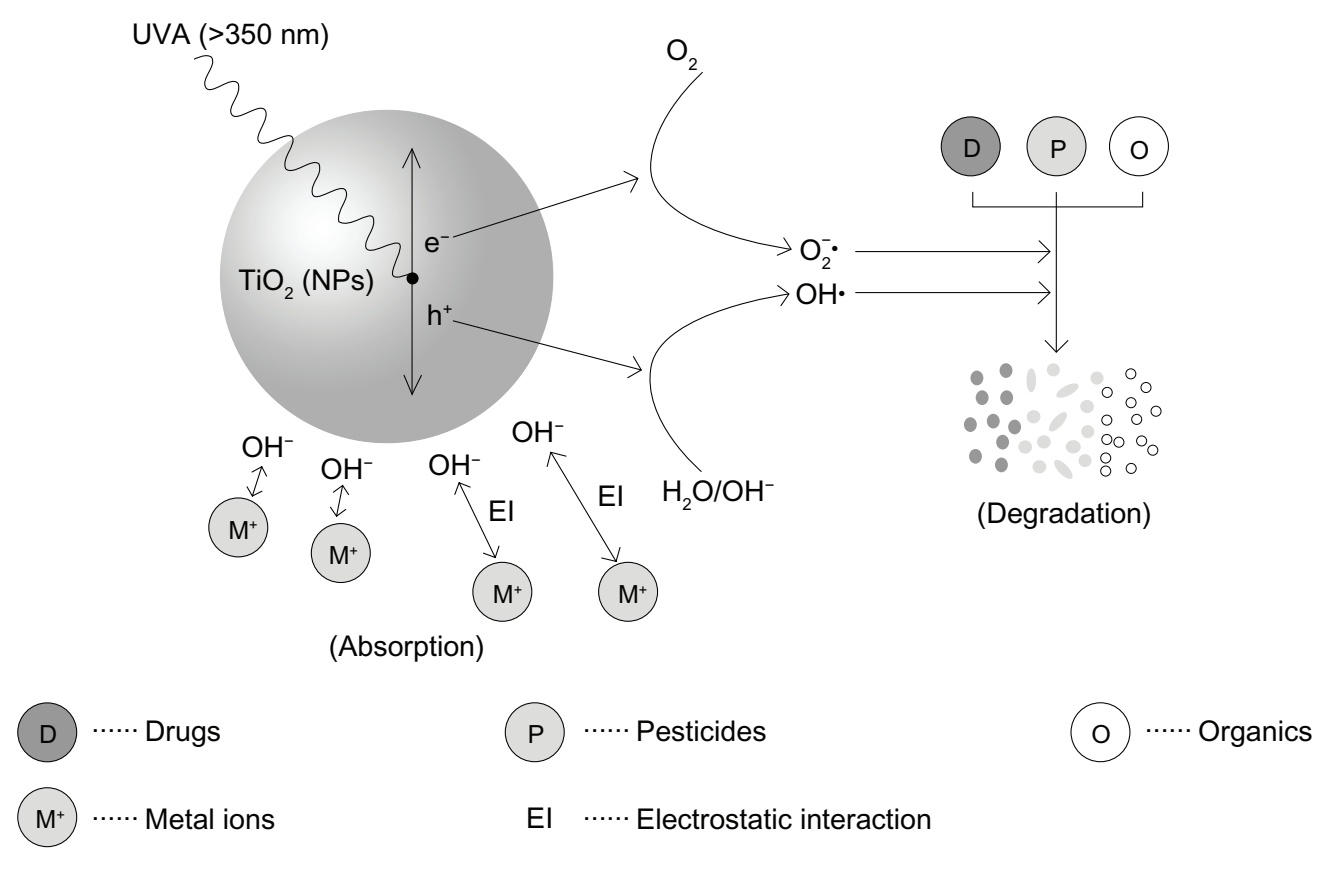

Figure 2 Interactive effects (degradation and absorption) of titanium dioxide $\left(\mathrm{TiO}_{2}\right.$ ) nanoparticles (NPs) with chemicals under ultraviolet $\mathrm{A}$ (UVA) radiation. Abbreviations: $\mathrm{OH}$, hydroxyl radicals; $\mathrm{O}_{2}$, oxygen; $\mathrm{O}_{2}$, superoxide radical; $\mathrm{H}_{2} \mathrm{O}$, water; $\mathrm{e}^{-}$, electron; $\mathrm{h}^{+}$, the positive hole. 
Table 2 Studies in vivo on the interactive effects of $\mathrm{TiO}_{2} \mathrm{NPs}$ with chemicals or physical factors

\begin{tabular}{|c|c|c|c|c|c|c|}
\hline \multirow[t]{2}{*}{ Reference } & \multirow[t]{2}{*}{ Supplier } & \multicolumn{3}{|c|}{ Characteristics of $\mathrm{TiO}_{2} \mathrm{NP}$} & \multirow{2}{*}{$\begin{array}{l}\text { Dispersion } \\
\text { method }\end{array}$} & \multirow{2}{*}{$\begin{array}{l}\text { Living } \\
\text { organism }\end{array}$} \\
\hline & & $\begin{array}{l}\text { Particle } \\
\text { size }(\mathrm{nm})\end{array}$ & $\begin{array}{l}\text { Crystal } \\
\text { structure }\end{array}$ & $\begin{array}{l}\text { Surface } \\
\text { area }\left(\mathrm{m}^{2} / \mathrm{g}\right)\end{array}$ & & \\
\hline 20 & $\begin{array}{l}\text { Zhejiang Hongsheng } \\
\text { Nanotechnology }\end{array}$ & 50,120 & NA & NA & $\begin{array}{l}\text { Sonicated for } \\
20 \mathrm{~min}\end{array}$ & $\begin{array}{l}\text { Kun Ming } \\
\text { mice }\end{array}$ \\
\hline 32 & $\begin{array}{l}\text { Skyspring } \\
\text { Nanomaterials Inc }\end{array}$ & $5-10$ & NA & NA & $\begin{array}{l}\text { Mixed in a } \\
\text { shaker for } 24 \mathrm{~h}\end{array}$ & $\begin{array}{l}\text { Ceriodaphnia } \\
\text { dubia }\end{array}$ \\
\hline 35 & $\begin{array}{l}\text { Nanjing High } \\
\text { Technology Material }\end{array}$ & 13.5 & Anatase & NA & $\begin{array}{l}\text { Sonicated for } \\
\text { at least } 30 \mathrm{~min}\end{array}$ & $\begin{array}{l}\text { Daphnia } \\
\text { magna }\end{array}$ \\
\hline 41 & Degussa & 21 & NA & 50 & NA & Cyprinus carpio \\
\hline 42 & Evonik Degussa & 21 & NA & $50 \pm 15$ & $\begin{array}{l}\text { Pre-equilibrated } \\
\text { for at least } 24 \mathrm{~h}\end{array}$ & Zebrafish \\
\hline 43 & Vivo Nano & $1-10$ & Anatase & NA & $\begin{array}{l}\text { Coated with } \\
\text { hydrophilic sodium } \\
\text { polyacrylate }\end{array}$ & $\begin{array}{l}\text { Chlamydomonas } \\
\text { reinhardtii }\end{array}$ \\
\hline 58 & Degussa & 21 & NA & NA & $\begin{array}{l}\text { Ultrasonicated } \\
\text { for } 10 \mathrm{~min}\end{array}$ & $\begin{array}{l}\text { Micrococcus } \\
\text { lysodeikticus }\end{array}$ \\
\hline 69 & Alfa Aesar & $5,10,32$ & NA & $210,115,45$ & NA & Xenopus laevis 0 \\
\hline 75 & Sigma-Aldrich & NA & $\begin{array}{l}\text { Anatase } \\
\text { and rutile }\end{array}$ & NA & $\begin{array}{l}\text { Sonicated for } \\
30 \mathrm{~min}\end{array}$ & $\begin{array}{l}\text { Female BALB/c } \\
\text { nude mice }\end{array}$ \\
\hline 79 & Degussa & 21 & $\begin{array}{l}80 \% \text { anatase, } \\
20 \% \text { rutile }\end{array}$ & $50 \pm 15$ & $\begin{array}{l}\text { Sonicated for } \\
10 \text { min }\end{array}$ & D. magna \\
\hline 80 & Degussa & 27 & NA & 50 & $\begin{array}{l}\text { Dispersed on } 5 \mathrm{~A} \\
\text { or } 13 \mathrm{X} \text { surface }\end{array}$ & $\begin{array}{l}\text { Vibrio } \\
\text { qinghaiensis } \\
\text { sp.-Q67 }\end{array}$ \\
\hline
\end{tabular}

Note: ${ }^{\mathrm{T}}$ The combined effects are effects with $\mathrm{TiO}_{2} \mathrm{NPs}$ and combined factors, comparing with effects of $\mathrm{nTiO}$, or combined factor alone.

Abbreviations: $\downarrow$, inhibit, decrease, suppress, or delay; $\uparrow$, increase; $\leftrightarrow$, no significant changes; GSH, glutathione; NA, data not available; NPs, nanoparticles; ROS, reactive oxygen species; $\mathrm{SOD}$, superoxide dismutase; $\mathrm{T}$, temperature; $\mathrm{TiO}_{2}$, titanium dioxide; UVA, ultraviolet $\mathrm{A} ; \mathrm{MDA}$, malondialdehyde; $\mathrm{CD}$, cadmium; $\mathrm{HA}$, humic acid; $\mathrm{NaH}{ }_{2} \mathrm{As} \mathrm{O}_{4}$, sodiumarsenate; OTC, oxytetracycline; min, minutes; $\mathrm{PbAC}$, Plumbi Acetatis; h, hours; d, days; $\mathrm{pH}$, the acidity or basicity of an aqueous solution; $\mathrm{nTiO}{ }_{2}$, nano- $\mathrm{TiO}$.

of the death receptor Fas, and activation of the preapoptotic protein Bax. ${ }^{86}$ Meanwhile, ROS-induced p53-mediated DNA damage can lead to $\mathrm{G}_{2} / \mathrm{M}$ cell-cycle arrest or delay and mitochondrial DNA damage. ${ }^{67,69,88}$ These procedures can ultimately lead to cell apoptosis. This combined toxicity could be alleviated by antioxidant NAC. The combined effects of $\mathrm{TiO}_{2}$ NPs and UVA are a double-edged sword. Synergistic effects in ROS generation and cytotoxicity after a combination of $\mathrm{TiO}_{2}$ NPs and UVA irradiation may be beneficial in the treatment of tumors. A combination of $\mathrm{TiO}_{2} \mathrm{NPs}_{\mathrm{S}}$ and UVA irradiation may also be helpful in degradation of pesticide or drug content in the environment. The beneficial effects also include enhancement in bactericidal activity. However, degradation may also be a possible contributor. An enhancement in toxicity in the ecosystem occurs when higher toxics are degraded and byproducts are generated. Therefore, more studies are necessary to elucidate the effects of the interaction of $\mathrm{TiO}_{2} \mathrm{NPs}$ with different drugs or pesticides in ecosystems under UV radiation.

\section{Summary}

Research data on the effects of the interaction of $\mathrm{TiO}_{2} \mathrm{NPs}$ with chemicals or physical factors are emerging slowly. Experimental factors such as agglomeration/aggregation of NPs, cell type, dispersion method, or culture medium may all affect the experiment results, ${ }^{15,88-90}$ which may inevitably cause difficulties in interpreting these results. To give the whole picture of the experiments, we summarize in detail the combined toxicities of $\mathrm{TiO}_{2}$ and chemicals or physical factors for all available studies in Tables 1 and 2 .

The existing evidence suggests that $\mathrm{TiO}_{2}$ NPs can absorb metals, including $\mathrm{Pb}, \mathrm{As}, \mathrm{Cu}$, and $\mathrm{Cd}$, or their ions in solution. A combination of $\mathrm{TiO}_{2} \mathrm{NPs}$ with metals, organic or inorganic compounds such as BPA, p,p-DDT, or $\mathrm{NaF}$, and physical factors such as UVA light can result in an increase in oxidative stress and toxicity in culture cells or in aquatic animals. Oxidative stress may further induce tumor gene expression or lead to nuclear and mitochondrial DNA damage in mammalian cells. Further well-designed studies are necessary to 


\begin{tabular}{|c|c|c|c|c|}
\hline $\begin{array}{l}\text { Exposure } \\
\text { concentration }\end{array}$ & $\begin{array}{l}\text { Exposure } \\
\text { method }\end{array}$ & $\begin{array}{l}\text { Exposure } \\
\text { time }\end{array}$ & $\begin{array}{l}\text { Exposure condition of combined } \\
\text { factors and experiment }\end{array}$ & Combined effects $^{a}$ \\
\hline $5 \mathrm{~g} / \mathrm{kg}$ & Oral gavage & $7 d$ & $\mathrm{PbAC:} 500 \mathrm{mg} / \mathrm{kg}$ & $\begin{array}{l}\text { Liver and kidney function } \downarrow ; \text { ROS: liver } \uparrow \text {, } \\
\text { kidney/cortex/hippocampus } \leftrightarrow \text {; MDA } \leftrightarrow \text {; } \\
\text { liver/kidney: SOD } \leftrightarrow, G S H-P x \leftrightarrow, \text { cortex } \\
\text { and hippocampus: SOD } \downarrow, G S H-P x \downarrow\end{array}$ \\
\hline $200 \mathrm{mg} / \mathrm{L}$ & In food & $24 \mathrm{~h}$ & $\begin{array}{l}\mathrm{NaH}_{2} \mathrm{AsO}_{4}: 0,0.45,0.75, \mathrm{I} .5,2.25,2.5 \\
3, \text { and } 4.5 \mathrm{mg} / \mathrm{L} ; \mathrm{pH}=7.8, \mathrm{~T}=20^{\circ} \mathrm{C}\end{array}$ & $\begin{array}{l}\mathrm{TiO}_{2} \text { NPs concentration: mortality at low } \\
\text { dose } \uparrow ; \text { mortality at high dose } \downarrow\end{array}$ \\
\hline $2 \mathrm{mg} / \mathrm{L}$ & In water & $3 d$ & $\begin{array}{l}\text { Copper nitrate: } 10,20,30,40,50,70 \\
\text { and } 100 \mu \mathrm{g} / \mathrm{L} ; \mathrm{pH}=7.6, \mathrm{~T}=23^{\circ} \mathrm{C}\end{array}$ & $\mathrm{Cu}^{2+} \mathrm{LC} 50 \downarrow$, metallothionein level $\downarrow$ \\
\hline $10.0 \pm 1.3 \mathrm{mg} / \mathrm{L}$ & In water & $\begin{array}{l}0,5,10 \\
15,20,25 \mathrm{~d}\end{array}$ & $\begin{array}{l}\mathrm{Cd}: 34.4 \pm 4.8 \mu \mathrm{g} / \mathrm{l}, 97.3 \pm 6.9 \mu \mathrm{g} / \mathrm{L} \\
\mathrm{pH}=7.8, \mathrm{~T}=23^{\circ} \mathrm{C} \pm 2^{\circ} \mathrm{C}\end{array}$ & Cd accumulation $\uparrow$ \\
\hline $5,10,20 \mathrm{mg} / \mathrm{L}$ & In water & $\begin{array}{l}0,1,2,5 \\
8,12,16,20 \mathrm{~d}\end{array}$ & $\begin{array}{l}\mathrm{HA}: 5,10,20 \mathrm{mg} / \mathrm{L} ; \mathrm{Cd}: 50 \mu \mathrm{g} / \mathrm{L} \\
\mathrm{pH}=7.0, \mathrm{~T}=25^{\circ} \mathrm{C} \pm 2^{\circ} \mathrm{C}\end{array}$ & $\begin{array}{l}\text { Uptake rate constants of } \mathrm{Cd} \\
\text { bioaccumulation: } \mathrm{HA} / \mathrm{TiO}_{2} \uparrow, \mathrm{HA} \& \mathrm{TiO}_{2} \downarrow\end{array}$ \\
\hline $\begin{array}{l}\mathrm{I}, 3,10,30 \text {, and } \\
100 \mathrm{mg} / \mathrm{L}\end{array}$ & In water & $\begin{array}{l}0,0.25,0.5 \\
0.75, \mathrm{I}, 2,6 \mathrm{~h}\end{array}$ & $\begin{array}{l}\mathrm{Cd}: 0,0.1,0.3,0.5,0.8, \mathrm{I} .0 \text {, and } \\
3.0 \mathrm{mg} / \mathrm{L} ; \mathrm{pH}=7.5 \pm 0.1, \mathrm{~T}=25^{\circ} \mathrm{C}\end{array}$ & Free $\mathrm{Cd}^{2+}$ concentration in media $\downarrow$ \\
\hline $\begin{array}{l}0,2,4,6,8,10,15 \\
20,25,30,40,50,60 \\
80, \text { and } 100 \mathrm{mg} / \mathrm{L}\end{array}$ & In water & $10 \mathrm{~min}$ & $\begin{array}{l}\text { Lysozymes: } 0,0.42,0.97,1.39 \\
2.08 \mu \mathrm{M} ; \mathrm{pH}=7.4\end{array}$ & Bacteriolysis activity of lysozyme $\downarrow$ \\
\hline $\begin{array}{l}31, \mathrm{I}, 3.1,10,31,100 \\
310 \text {, and } 1000 \mathrm{mg} / \mathrm{L}\end{array}$ & In water & $14 \mathrm{~d}$ & UVA: $400 \mathrm{~mW} / \mathrm{m}^{2} ; \mathrm{pH}=7.0 \sim 7.8$ & $\begin{array}{l}X \text {. laevis survival } \downarrow \text {; tadpole: body length } \downarrow \text {, } \\
\text { development stages } \downarrow \text {, }\end{array}$ \\
\hline $200 \mu \mathrm{g}$ per tumor & Air pouch & $12 \mathrm{~h}$ & UVA: $365 \mathrm{~nm}, 5 \mathrm{~J} / \mathrm{cm}^{2}, 30 \mathrm{~min}$ & $\begin{array}{l}\text { Necrosis } \uparrow \text {, apoptosis } \uparrow \text {, tumor growth } \downarrow \text {, } \\
\text { survival } \uparrow\end{array}$ \\
\hline $\begin{array}{l}0.02,0.2, \text { and } \\
2.0 \mathrm{mg} / \mathrm{L}\end{array}$ & In water & $72 \mathrm{~h}$ & $\begin{array}{l}\text { Pirimicarb: } 20 \mu \mathrm{g} / \mathrm{L} ; \text { UVA: } 300-400 \mathrm{~nm} \\
40 \pm 5 \mathrm{~W} / \mathrm{m}^{2}, 15 \mathrm{~min} ; \mathrm{T}=20^{\circ} \mathrm{C} \pm 1^{\circ} \mathrm{C}\end{array}$ & $\begin{array}{l}\text { UVA and } \mathrm{nTiO}_{2}: \text { pirimicard } \\
\text { concentration } \downarrow\end{array}$ \\
\hline $\mathrm{I}, 5, \mathrm{I0}$, and $\mathrm{I} 5 \mathrm{wt} \%$ & In solution & $\begin{array}{l}30,60 \\
270 \mathrm{~min}\end{array}$ & $\begin{array}{l}\text { OTC: } 50 \mathrm{mg} / \mathrm{L} ; \text { UVA: } 254 \mathrm{~nm} \\
845 \mu \mathrm{W} / \mathrm{cm}^{2}, 2 \mathrm{~h} ; \mathrm{pH}=7\end{array}$ & $\begin{array}{l}\left(\mathrm{TiO}_{2} / 5 \mathrm{~A} \text { or } \mathrm{TiO}_{2} / / 3 \mathrm{X}\right) \text { and UVA: } \\
\text { inhibition rate } \uparrow\end{array}$ \\
\hline
\end{tabular}

elucidate possible mechanisms of these combined effects. In addition, combined toxicity of $\mathrm{TiO}_{2} \mathrm{NPs}$ with $\mathrm{ZnO} / \mathrm{Fe}_{3} \mathrm{O}_{4}$ is yet to be investigated by molecular biological and toxicological experiments. Meanwhile, studies on the combined toxicity of $\mathrm{TiO}_{2}$ NPs with other nanosized particles in toxicology and nanomedicine are also urgently needed. Human epidemiological investigation on the combination of $\mathrm{TiO}_{2} \mathrm{NPs}$ with other chemicals is urgently encouraged because $\mathrm{TiO}_{2} \mathrm{NPs}$ are increasingly being used as drug carriers in nanomedicine. Studies on the combined effects of $\mathrm{TiO}_{2}$ NPs with chemicals or physical factors on aquatic animals are also urgently needed. In addition, the combined effects of $\mathrm{TiO}_{2}$ NPs with chemicals or physical factors may serve as a double-edged sword. Therefore, studies are also encouraged for $\mathrm{TiO}_{2} \mathrm{NP}$ application in heavy metal pollution prevention and tumor treatment.

\section{Acknowledgments}

The excellent assistance of Miss Ruth Magaye, Mrs Linda Bowman, and Mr Yaseen Habeeb in the preparation of this article is greatly appreciated. This work was partly supported by the National Nature Science Foundation of China (Grant No 81273111), the Foundations of Innovative Research Team of Educational Commission of Zhejiang Province (T200907), the Nature Science Foundation of Ningbo City (Grant No 2012A610185), the Ningbo Scientific Project (Grant Nos 2012C5019 and SZX11073), the Scientific Innovation Team Project of Ningbo (No 2011B82014), Innovative Research Team of Ningbo (2009B21002), and KC Wong Magna Fund in Ningbo University.

\section{Disclosure}

The authors report no conflicts of interest in this work.

\section{References}

1. Hagens WI, Oomen AG, de Jong WH, Cassee FR, Sips AJ. What do we (need to) know about the kinetic properties of nanoparticles in the body? Regul Toxicol Pharmacol. 2007;49:217-229.

2. Magaye R, Zhao J, Bowman L, Ding M. Genotoxicity and carcinogenicity of cobalt-, nickel- and copper-based nanoparticles. Exp Ther Med. 2012;4:551-561. 
3. Zhao J, Castranova V. Toxicology of nanomaterials used in nanomedicine. Toxicol Environ Health B Crit Rev. 2011;14:593-632.

4. Cho WS, Kang BC, Lee JK, Jeong J, Che JH, et al. Comparative absorption, distribution, and excretion of titanium dioxide and zinc oxide nanoparticles after repeated oral administration. Particle and fibre toxicology. 2013;10:9.

5. Long TC, Tajuba J, Sama P, Saleh N, Swartz C, et al. Nanosize titanium dioxide stimulates reactive oxygen species in brain microglia and damages neurons in vitro. Environ Health Perspect. 2007;115: 1631-1637.

6. Li SQ, Zhu RR, Zhu H, Xue M, Sun XY, et al. Nanotoxicity of $\mathrm{TiO}_{2}$ nanoparticles to erythrocyte in vitro. Food Chem Toxicol. 2008;46: 3626-3631.

7. Magaye R, Zhao J. Recent progress in studies of metallic nickel and nickel-based nanoparticles' genotoxicity and carcinogenicity. Environ Toxicol Pharmacol. 2012;34:644-650.

8. Zhao J, Bowman L, Zhang X, Vallyathan V, Young SH, et al. Titanium dioxide $\left(\mathrm{TiO}_{2}\right)$ nanoparticles induce JB6 cell apoptosis through activation of the caspase-8/Bid and mitochondrial pathways. JToxicol Environ Health A. 2009;72:1141-1149.

9. Buzea C, Pacheco, II, Robbie K. Nanomaterials and nanoparticles: sources and toxicity. Biointerphases. 2007;2:17-71.

10. Jawad H, Boccaccini AR, Ali NN, Harding SE. Assessment of cellular toxicity of $\mathrm{TiO}_{2}$ nanoparticles for cardiac tissue engineering applications. Nanotoxicology. 2011;5:372-380.

11. Lee KP, Trochimowicz HJ, Reinhardt CF. Pulmonary response of rats exposed to titanium dioxide $\left(\mathrm{TiO}_{2}\right)$ by inhalation for two years. Toxicol Appl Pharmacol. 1985;79:179-192.

12. ZeY, Hu R, Wang X, Li B, Su J, et al. Neurotoxicity and gene-expressed profile in brain injured mice caused by exposure to titanium dioxide nanoparticles. J Biomed Mater Res A. March 27, 2013;00A:3-9 [Epub ahead of print.]

13. Iavicoli I, Leso V, Bergamaschi A. Toxicological effects of titanium dioxide nanoparticles: a review of in vivo studies. J Nanomater. 2012;2012:5.

14. Magdolenova Z, Collins AR, Kumar A, Dhawam A, Stone V, et al. Mechanisms of genotoxicity: review of recent in vitro and in vivo studies with engineered nanoparticles. Nanotoxicology. 2013:1-73.

15. Shi H, Magaye R, Castranova V, Zhao J. Titanium dioxide nanoparticles: a review of current toxicological data. Part Fibre Toxicol. 2013;10:15.

16. Sharma VK. Aggregation and toxicity of titanium dioxide nanoparticles in aquatic environment: a review. J Environ Sci Health A Tox Hazard Subst Environ Eng. 2009;44:1485-1495.

17. Hartmann NB, Legros S, Von der Kammer F, Hofmann T, Baun A. The potential of $\mathrm{TiO}_{2}$ nanoparticles as carriers for cadmium uptake in Lumbriculus variegatus and Daphnia magna. Aquat Toxicol. 2012;118-119:1-8.

18. Tavallali H. Alumina-coated magnetite nanoparticles for solid phase extraction of Cd in water samples. Chem Tech. 2011;3:1647-1651.

19. Mashhadizadeh MH, Karami Z. Solid phase extraction of trace amounts of $\mathrm{Ag}, \mathrm{Cd}, \mathrm{Cu}$, and $\mathrm{Zn}$ in environmental samples using magnetic nanoparticles coated by 3-(trimethoxysilyl)-1-propantiol and modified with 2-amino-5-mercapto-1,3,4-thiadiazole and their determination by ICP-OES. J Hazard Mater. 2011;190: $1023-1029$

20. Zhang R, Niu Y, Li Y, Zhao C, Song B, et al. Acute toxicity study of the interaction between titanium dioxide nanoparticles and lead acetate in mice. Environ Toxicol Pharmacol. 2010;30:52-60.

21. Bakircioglu Y, Bakircioglu D, Akman S. Biosorption of lead by filamentous fungal biomass-loaded $\mathrm{TiO}_{2}$ nanoparticles. J Hazard Mater. 2010;178:1015-1020.

22. Kalfa OM, Yalçınkaya Ö, Türker AR. Synthesis of nano $\mathrm{B}_{2} \mathrm{O}_{3} / \mathrm{TiO}_{2}$ composite material as a new solid phase extractor and its application to preconcentration and separation of cadmium. J Hazard Mater. 2009;166:455-461.
23. Du H, Zhu X, Fan C, Xu S, Wang Y, et al. Oxidative damage and OGG1 expression induced by a combined effect of titanium dioxide nanoparticles and lead acetate in human hepatocytes. Environmental Toxicology. 2011;27:590-597.

24. Barchowsky A, Cartwright IL, Reichard JF, Futscher BW, Lantz RC. Arsenic toxicology: translating between experimental models and human pathology. Environ Health Perspect. 2011;119:1356.

25. Guan X, Du J, Meng X, Sun Y, Sun B, et al. Application of titanium dioxide in arsenic removal from water: a review. J Hazard Mater. 2012; 215-216:1-16.

26. Liu Y, Liang P, Guo L, Lu HB. Study on the adsorption behavior of heavy metal ions on nanometer $\mathrm{TiO}_{2}$ supported on silica gel [in Chinese]. Acta Chim Sin. 2005;63:312-316.

27. Bleam WF, McBride MB. The chemistry of adsorbed $\mathrm{Cu}$ (II) and $\mathrm{Mn}$ (II) in aqueous titanium dioxide suspensions. J Colloid Interface Sci. 1986;110:335-346.

28. Pena ME, Korfiatis GP, Patel M, Lippincott L, Meng X. Adsorption of As (V) and As (III) by nanocrystalline titanium dioxide. Water Research. 2005;39:2327-2337.

29. Bang S, Patel M, Lippincott L, Meng X. Removal of arsenic from groundwater by granular titanium dioxide adsorbent. Chemosphere. 2005;60:389-397.

30. Niu HY, Wang JM, Shi YL, et al. Adsorption behavior of arsenic onto protonated titanate nanotubes prepared via hydrothermal method. Micropor Mesopor Mat. 2009;122:28-35.

31. Jegadeesan G, Al-Abed SR, Sundaram V, Choi H, Scheckel KG, et al. Arsenic sorption on $\mathrm{TiO}_{2}$ nanoparticles: size and crystallinity effects. Water Research. 2010;44:965-973.

32. Wang D, Hu J, Irons DR, Wang J. Synergistic toxic effect of nano-TiO, and As (V) on Ceriodaphnia dubia. STOTEN. 2011;409:1351-1356.

33. Malkin R, Malmström BG. The state and function of copper in biological systems. Adv Enzymol Relat Areas Mol Biol. 1970:177-244.

34. Mitra S, Keswani T, Dey M, Bhattacharya S, Sarkar S, et al. Copperinduced immunotoxicity involves cell cycle arrest and cell death in the spleen and thymus. Toxicology. 2012;293:1-3.

35. Fan W, Cui M, Liu H, Wang C, Shi Z, et al. $\mathrm{NanoTiO}_{2}$ enhances the toxicity of copper in natural water to Daphnia magna. Environ Pollut. 2011;159:729-734.

36. Kjellström T. Mechanism and epidemiology of bone effects of cadmium. IARC Scientific Publications. 1992:301.

37. Nordberg GF, Herber RFM, Alessio L. Cadmium in the human environment: toxicity and carcinogenicity. International Agency for Research on Cancer; 1992.

38. Flick D, Kraybill H, Dlmitroff J. Toxic effects of cadmium: a review. Environmental Research. 1971;4:71-85.

39. Järup L. Hazards of heavy metal contamination. British Medical Bulletin. 2003;68:167-182.

40. Xia B, Chen J, Zhou Y. Cellular oxidative damage of HEK293T cells induced by combination of $\mathrm{CdCl}_{2}$ and $\mathrm{Nano}^{-\mathrm{TiO}_{2}}$. Journal of Huazhong University of Science and Technology Medical Sciences. 2011;31:290-294.

41. Zhang X, Sun H, Zhang Z, Niu Q, Chen Y, et al. Enhanced bioaccumulation of cadmium in carp in the presence of titanium dioxide nanoparticles. Chemosphere. 2007;67:160-166.

42. Hu X, Chen Q, Jiang L, Yu Z, Jiang D, et al. Combined effects of titanium dioxide and humic acid on the bioaccumulation of cadmium in zebrafish. Environ Pollut. 2011;159:1151-1158.

43. Yang WW, Miao AJ, Yang LY. $\mathrm{Cd}^{2+}$ Toxicity to a green alga Chlamydomonas reinhardtii as influenced by its adsorption on $\mathrm{TiO}_{2}$ engineered nanoparticles. PLoS One. 2012;7:e32300.

44. Shukla RK, Kumar A, Gurbani D, Pandey AK, Singh S, et al. $\mathrm{TiO}_{2}$ nanoparticles induce oxidative DNA damage and apoptosis in human liver cells. Nanotoxicology. 2011:1-13.

45. Shukla RK, Sharma V, Pandey AK, Singh S, Sultana S, et al. ROSmediated genotoxicity induced by titanium dioxide nanoparticles in human epidermal cells. Toxicol In Vitro. 2011;25:231-241. 
46. Huang Y, Wong C, Zheng J, Bouwman H, Barra R, et al. Bisphenol A (BPA) in China: a review of sources, environmental levels, and potential human health impacts. Environment International. 2011;42:91-99.

47. Alexander HC, Dill DC, Smith LW, Guiney PD, Dorn P. Bisphenol A: acute aquatic toxicity. Environ Toxicol Chem. 1988;7:19-26.

48. Woodruff TJ, Zota AR, Schwartz JM. Environmental chemicals in pregnant women in the United States: NHANES 2003-2004. Environ Health Perspect. 2011;119:878-885.

49. Zheng D, Wang N, Wang X, Tang Y, Zhu L, et al. Effects of the interaction of $\mathrm{TiO}_{2}$ nanoparticles with bisphenol A on their physicochemical properties and in vitro toxicity. J Hazard Mater. 2012;199-200:426-432.

50. Cohn BA, Wolff MS, Cirillo PM, Sholtz RI. DDT and breast cancer in young women: new data on the significance of age at exposure. Environ Health Perspect. 2007;115:1406.

51. Rogan WJ, Chen A. Health risks and benefits of bis (4-chlorophenyl)1,1,1-trichloroethane (DDT). Lancet. 2005;366:763-773.

52. Rogan WJ, Ragan NB. Evidence of effects of environmental chemicals on the endocrine system in children. Pediatrics. 2003;112:247-252.

53. Zoro J, Hunter JM, Eglinton G, Ware G. Degradation of p,p'-DDT in reducing environments. Nature. 1974;247:235-237.

54. Garrison AW, Nzengung VA, Avants JK, Ellington JJ, Jones WJ, et al. Phytodegradation of $\mathrm{p}, \mathrm{p}^{\prime}$-DDT and the enantiomers of $\mathrm{o}, \mathrm{p}^{\prime}$-DDT. Environmental Science and Technology. 2000;34:1663-1670.

55. Shi Y, Zhang JH, Jiang M, Zhu LH, Tan HQ, et al. Synergistic genotoxicity caused by low concentration of titanium dioxide nanoparticles and p, p'-DDT in human hepatocytes. Environ Mol Mutagen. 2010;51: 192-204.

56. O’Mullane DM, Kavanagh D, Ellwood RP, Chesters RK, Schafer F, et al. A three-year clinical trial of a combination of trimetaphosphate and sodium fluoride in silica toothpastes. J Dent Res. 1997;76: 1776-1781.

57. Xie C, Liang GY, Ye B, Pu YP. Combined effects of sodium fluoride and nano- $\mathrm{TiO}_{2}$ on human bronchial epithelial cells. Journal of Environmental and Occupational Medicine. 2009;26:242-244.

58. Xu Z, Liu XW, Ma YS, Gao HW. Interaction of nano-TiO 2 with lysozyme: insights into the enzyme toxicity of nanosized particles. Environ Sci Pollut Res Int. 2010;17:798-806.

59. Hui YLS. Research progress and application of photocatalysis of $\mathrm{TiO}_{2}$. Materials Review. 2000;12:23-25.

60. Kwon S, Fan M, Cooper AT, Yang H. Photocatalytic applications of micro-and nano- $\mathrm{TiO}_{2}$ in environmental engineering. Crit Rev Environ Sci Technol. 2008;38:197-226.

61. Aarthi T, Madras G. Photocatalytic degradation of rhodamine dyes with nano-TiO, . Ind Eng Chem Res. 2007;46:7-14

62. Yu H, Zhang K, Rossi C. Experimental study of the photocatalytic degradation of formaldehyde in indoor air using a nano-particulate titanium dioxide photocatalyst. Indoor and Built Environment. 2007;16: 529-537.

63. Wu YP, Zhang WM, Ma CF, Lu YW, Liu L. Photocatalytic degradation of formaldehyde by diffuser of solar light pipe coated with nanometer titanium dioxide thin films. Science China Technological Sciences. 2010;53:150-154.

64. Lu N, Zhu Z, Zhao X, Tao R, Yang X, et al. Nano titanium dioxide photocatalytic protein tyrosine nitration: a potential hazard of $\mathrm{TiO}_{2}$ on skin. Biochem Biophys Res Commun. 2008;370:675-680.

65. Tu M, Huang Y, Li HL, Gao ZH. The stress caused by nitrite with titanium dioxide nanoparticles under UVA irradiation in human keratinocyte cell. Toxicology. 2012;299:60-68.

66. Xue C, Wu J, Lan F, Liu W, Yang X, et al. Nano titanium dioxide induces the generation of ROS and potential damage in $\mathrm{HaCaT}$ cells under UVA irradiation. J Nanosci Nanotechnol. 2010;10: 8500-8507.

67. Kang SJ, Lee YJ, Kim BM, Choi YJ, Chung HW. Cytotoxicity and genotoxicity of titanium dioxide nanoparticles in UVA-irradiated normal peripheral blood lymphocytes. Drug Chem Toxicol. 2011;34: $277-284$.
68. Yin JJ, Liu J, Ehrenshaft M, Roberts JE, Fu PP, et al. Phototoxicity of nano titanium dioxides in $\mathrm{HaCaT}$ keratinocytes - generation of reactive oxygen species and cell damage. Toxicol Appl Pharmacol. 2012;263: 81-88.

69. Zhang J, Wages M, Cox SB, Maul JD, LiY, et al. Effect of titanium dioxide nanomaterials and ultraviolet light coexposure on African clawed frogs (Xenopus laevis). Environ Toxicol Chem. 2012;31:176-183.

70. Bar-Ilan O, Louis KM, Yang SP, Pedersen JA, Hamers RJ, et al. Titanium dioxide nanoparticles produce phototoxicity in the developing zebrafish. Nanotoxicology. 2012;6:670-679.

71. Xue C, Liu W, Wu J, Yang X, Xu H. Chemoprotective effect of N-acetylcysteine (NAC) on cellular oxidative damages and apoptosis induced by nano titanium dioxide under UVA irradiation. Toxicology In Vitro. 2011;25:110-116.

72. Smilkstein MJ, Knapp GL, Kulig KW, Rumack BH. Efficacy of oral $\mathrm{N}$-acetylcysteine in the treatment of acetaminophen overdose. Analysis of the national multicenter study (1976 to 1985). N Engl J Med. 1988;319:1557.

73. Aruoma OI, Halliwell B, Hoey BM, Butler J. The antioxidant action of $\mathrm{N}$-acetylcysteine: its reaction with hydrogen peroxide, hydroxyl radical, superoxide, and hypochlorous acid. Free Radical Biology and Medicine. 1989;6:593-597.

74. Pannu N, Manns B, Lee H, Tonelli M. Systematic review of the impact of $\mathrm{N}$-acetylcysteine on contrast nephropathy. Kidney Int. 2004;65:1366-1374.

75. Wang C, Cao S, Tie X, Qiu B, Wu A, et al. Induction of cytotoxicity by photoexcitation of $\mathrm{TiO}_{2}$ can prolong survival in glioma-bearing mice. Mol Biol Rep. 2011;38:523-530.

76. Moon J, Yun CY, Chung K-W, Kang M-S, Yi J. Photocatalytic activation of $\mathrm{TiO}_{2}$ under visible light using Acid Red 44. Catalysis Today. 2003;87:77-86.

77. Srinivasan C, Somasundaram N. Bactericidal and detoxification effects of irradiated semiconductor catalyst, $\mathrm{TiO}_{2}$. Current Science-Bangalore. 2003;85:1431-1438.

78. Thomas J, Kumar KP, Chitra K. Synthesis of Ag doped nano $\mathrm{TiO}_{2}$ as efficient solar photocatalyst for the degradation of endosulfan. $\mathrm{Adv} \mathrm{Sci}$ Lett. 2011;4:108-114.

79. Seitz F, Bundschuh M, Dabrunz A, Bandow N, Schaumann GE, et al. Titanium dioxide nanoparticles detoxify pirimicarb under UV irradiation at ambient intensities. Environ Toxicol Chem. 2012;31: 518-523.

80. Zhao C, Deng H, Li Y, Liu Z. Photodegradation of oxytetracycline in aqueous by $5 \mathrm{~A}$ and $13 \mathrm{X}$ loaded with $\mathrm{TiO}_{2}$ under UV irradiation. J Hazard Mater. 2010;176:884-892.

81. Li M, Noriega-Trevino ME, Nino-Martinez N, Marambio-Jones C, Wang J, et al. Synergistic bactericidal activity of $\mathrm{Ag}-\mathrm{TiO}_{2}$ nanoparticles in both light and dark conditions. Environ Sci Technol. 2011;45: 8989-8995.

82. Song M, Zhang R, Dai Y, Gao F, Chi H, et al. The in vitro inhibition of multidrug resistance by combined nanoparticulate titanium dioxide and UV irradition. Biomaterials. 2006;27:4230-4238.

83. Liao D, Badour C, Liao B. Preparation of nanosized $\mathrm{TiO}_{2} / \mathrm{ZnO}$ composite catalyst and its photocatalytic activity for degradation of methyl orange. J Photochem Photobiol A Chem. 2008;194:11-19.

84. Panigrahi S, Basak D. Core-shell TiO $@$ @ $\mathrm{ZnO}$ nanorods for efficient ultraviolet photodetection. Nanoscale. 2011;3:2336-2341.

85. Jiang Y, Sun Y, Liu H, Zhu F, Yin H. Solar photocatalytic decolorization of CI Basic Blue 41 in an aqueous suspension of $\mathrm{TiO}_{2}-\mathrm{ZnO}$. Dyes Pigm. 2008;78:77-83.

86. Yoo K-C, Yoon C-H, Kwon D, Hyun K-H, Woo SJ, et al. Titanium dioxide induces apoptotic cell death through reactive oxygen speciesmediated Fas upregulation and Bax activation. Int J Nanomedicine. 2012;7:1203.

87. Sanders K, Degn LL, Mundy WR, Zucker RM, Dreher K, et al. in vitro phototoxicity and hazard identification of nano-scale titanium dioxide. Toxicol Appl Pharmacol. 2012;258:226-236. 
88. Lankoff A, Sandberg WJ, Wegierek-Ciuk A, Lisowska H, Refsnes M, et al. The effect of agglomeration state of silver and titanium dioxide nanoparticles on cellular response of HepG2, A549 and THP-1 cells. Toxicol Lett. 2012;208:197-213.

89. Ekstrand-Hammarström B, Akfur CM, Andersson PO, Lejon C, Österlund L, et al. Human primary bronchial epithelial cells respond differently to titanium dioxide nanoparticles than the lung epithelial cell lines A549 and BEAS-2B. Nanotoxicology. 2012;6:623-634.
90. Magdolenova Z, Bilaničová D, Pojana G, Fjellsbø LM, Hudecova A, et al. Impact of agglomeration and different dispersions of titanium dioxide nanoparticles on the human related in vitro cytotoxicity and genotoxicity. J Environ Monit. 2012;14:455-464.

\section{Publish your work in this journal}

The International Journal of Nanomedicine is an international, peerreviewed journal focusing on the application of nanotechnology in diagnostics, therapeutics, and drug delivery systems throughout the biomedical field. This journal is indexed on PubMed Central, MedLine, CAS, SciSearch $\AA$, Current Contents ${ }^{\circledR} /$ Clinical Medicine,
Journal Citation Reports/Science Edition, EMBase, Scopus and the Elsevier Bibliographic databases. The manuscript management system is completely online and includes a very quick and fair peer-review system, which is all easy to use. Visit http://www.dovepress.com/ testimonials.php to read real quotes from published authors. 